\title{
Nadir Bir Yan Etki Olarak Amlodipine Bağlı Dişeti Hiperplazisi
}

\section{A Rare Case Report of Amlodipine-Induced Gingival Hyperplasia}

\author{
Ayşe Pınar Göksu Çetinkaya ${ }^{1}$, Leyla Asgarova² (i) \\ ${ }^{1}$ istanbul Üniversitesi, İstanbul Tıp Fakültesi, Çocuk Sağlığı ve Hastalıkları Anabilim Dalı, Çocuk Nefroloji Bilim Dalı, İstanbul, Türkiye \\ ${ }^{2}$ İstanbul Üniversitesi, İstanbul Tıp Fakültesi, Çocuk Sağlığı ve Hastalıkları Anabilim Dalı, İstanbul, Türkiye
}

ORCID ID: A.P.G.Ç. 0000-0002-6258-0413; L.A. 0000-0001-9339-0500

Atıf/Citation: Goksu Cetinkaya, AP, Asgarova L. Nadir bir yan etki olarak amlodipine bağlı dişeti hiperplazisi. Çocuk Dergisi - Journal of Child 2020;20(1):3335. https://doi.org/10.26650/jchild.2020.1.0006

öz

Çocukluk çağında hipertansiyon tedavisinde kalsiyum kanal blokerleri en sık kullanılan ilaçlardandır. Dişeti hiperplazisi kalsiyum kanal blokeri kullanımının nadir yan etkilerindendir. Kalsiyum kanal blokerlerinden en sık nefidipine bağlı olarak görülmektedir. Daha az sıklıkla amlodipin kullanımıyla gözlenmektedir. Vakamızda düşük doz amlodipin tedavisi sırasında nadir bir yan etki olarak dişeti hiperplazisi gelişmişti. Bu olgu hipertansiyon nedeniyle tedavi alan hastalarda dişeti hiperplazisi gelişiminin amlodipin kullanımının yan etkisi sonucunda oluşabileceğini vurgulamak amacıyla bildirilmiştir.

Anahtar Kelimeler: Dişeti hiperplazisi, amlodipin, yan etki, hipertansiyon

\section{ABSTRACT}

Calcium channel blockers are the most commonly used drugs in the treatment of hypertension in childhood. Gingival hyperplasia is one of the rare side effects of calcium channel blocker use. Among calcium channel blockers, it is most commonly seen due to nephidipine. Gingival hyperplasia is less frequently observed with the use of amlodipine. In our case, gingival hyperplasia developed as a rare side effect during low dose amlodipine treatment. This case has been reported to emphasize that the development of gingival hyperplasia in patients with hypertension may be a side effect of amlodipine use.

Keywords: Gingival hyperplasia, amlodipine, side effect, hypertension

\section{GiRiş}

Dişeti hiperplazisi inflamatuar, idiyopatik, neoplazi, ergenlik ve hamilelik gibi hormonal değişikliklerle veya ilaçların kullanımı ile ilişkili olarak dişeti hacminin artmasıdır. Antikonvülzanlar, immünosüpresanlar ve kalsiyum kanal blokerleri gibi ilaçlar dişeti hiperplazisine yol açabilmektedir (Tablo 1) (1). Çocuklardaki sıklığı bilinmemektedir. Düşük doz amlodipin kullanımı sonrası dişeti hiperplazisi gelişen çocuk olgu sunuldu.

\section{OLGU}

Yedi yaş beş aylık erkek hasta, bilinen hastalığı yokken akut gastroenteritten 2 hafta sonra tüm vücutta ağrı, dizlerinde ve omuzlarında güçsüzlük şikayeti ile başvurdu. Guillain Barre tanısı ile serviste izlenen hasta plazmaferez ve intravenöz immunoglobulin tedavisi aldı. Servis takibinde kan basıncı yüksekliği saptandı. Renal doppler ultrasonografi, elektrokardiyografi ve ekokardiyografide patoloji saptanmadı. Hastaya
Tablo 1. Dişeti hiperplazisi gelişimine neden olan ilaçlar ve dişeti hiperplazisine neden olma oranları (1)

\begin{tabular}{lll}
\hline Antikolvülzanlar & Fenitoin (\%50) \\
& Sodyum valproat (\%10) \\
& Fenobarbital (<\%5) \\
& Vigabatrin (<\%5) \\
& Etosuksimid & \\
\hline Immünosüpresanlar & Siklosporin (\%22,4) \\
& Takrolimus (\%14,1) \\
& Sirolimus & \\
\hline Kalsiyum kanal blokerleri & Fenilalkilaminler & Verapamil (\%5) \\
& Benzodiazepinler & Diltiazem (\%5-20) \\
& Dihidropiridinler & Nifedipin (\%6-15) \\
& & Nitrendipin \\
& & Amlodipin (\%1,7-3,3) \\
& & Nikardipin \\
\hline
\end{tabular}

Sorumlu Yazar/Corresponding Author: Ayşe Pınar Göksu Çetinkaya E-mail: aysepinargoksu@gmail.com

Başvuru/Submitted: 08.01.2020 • Revizyon Talebi/Revision Requested: 22.03.2020 • Son Revizyon/Last Revision Received: 28.03 .2020 • Kabul/Accepted: 30.03.2020 


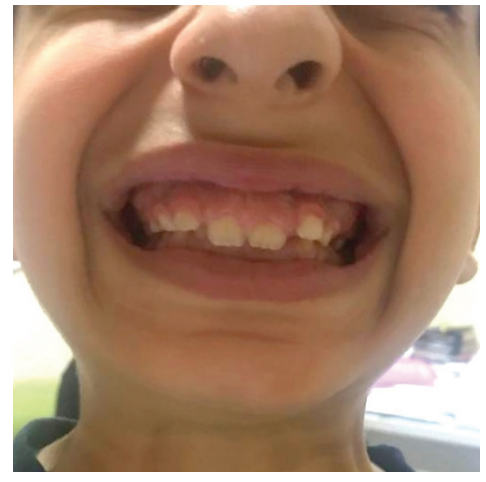

Resim 1. Amlodipin kullanımı sonrasında hastada gelişen dişeti hiperplazisi

amlodipin $1 \times 5 \mathrm{mg}$ ve doksazosin $2 \times 1 \mathrm{mg}$ başlandı, taburculuk sonrası hasta ileri tetkik ve takip amacıyla polikliniğe yönlendirildi.

Hastanın hipertansiyon etiyolojisine yönelik yapılan tetkiklerinden tiroid fonksiyon ve böbrek fonksiyon testleri, elektrolit düzeyleri, hemogramı, tam idrar tahlili normal bulundu. Göz muayenesi doğaldı. Renin aktivitesi $6,66 \mathrm{ng} / \mathrm{ml} / \mathrm{saat}$ (1,0-6,5 $\mathrm{ng} / \mathrm{mL} / \mathrm{saat}$ ); aldosteron $28,05 \mathrm{ng} / \mathrm{dl}$ (6-35 ng/dl) olarak sonuçlandı. Kan basıncı takibi yapılan hasta normotansif seyretti. Antihipertansif tedavi başlangıcından 3 ay sonra kesildi. Düzenli aralıklarla poliklinik kontrolüne çağırıldı. Poliklinik izleminde üriner ultrasonografide sol böbrekte grade 2 sağ böbrekte grade 1 pelviektazi saptandı. İşeme sistoüreterografisinde vezikoüreteral reflü saptanmadı. Takibinde diyastolik kan basıncı 95 . persentil üzerinde seyretmesi nedeniyle yapılan yaşam içi kan basıncı izleminde sistolik kan basıncında \%83, diyastolik kan basıncında \%69 sınır değeri aşma saptandı. Hastaya diyet ve egzersiz önerildi. Kontrol yaşam içi kan basıncı izleminde sistolik kan basıncında \%55, diyastolik kan basıncında \%50 sınır değerleri aşma saptandı. Antihipertansif tedavisinin kesilmesinden 16 ay sonra amlodipin $1 \times 2,5 \mathrm{mg}$ başlandı. Amlodipin başlandıktan 9 ay sonra diş ağrısı ile başvurduğunda diş eti hiperplazisi saptandı (Resim 1), kan basıncı değerleri de normotansifti. Amlodipin tedavisi kesildi. Amlodipin kesilmesinden sonra dişeti hiperplazisinde gerileme saptandı.

\section{TARTIŞMA}

Amlodipin çocukluk çağı hipertansiyon tedavisinde ilk tercih edilen ilaçlardan biridir. Ancak amlodipinin çeşitli yan etkileri bulunmaktadır (Tablo 2) (2). Dişeti hiperplazisi amlodipin kullanımının nadir bir yan etkisidir. İlk amlodipine bağlı dişeti hiperplazi vakası 1993 yılında bildirilmiştir (3). Jorgensen ve arkadaşlarının 1997 yılında yaptığı çalışmada, 150 hastanın 5 'inde $(\% 3,3)$ amlodipin kullanımına bağlı dişeti hiperplazisi tespit edildi (4). Ellis ve arkadaşlarının 1999 yılında yaptığı çalışmada 181 hastanın 3'ünde $(\% 1,7)$ (5) ve 2010 yılında Ono ve arkadaşları tarafindan yapılan çalışmada 301 hastanın 4'ünde $(\% 1,3)$ gingival hiperplazi tespit edildi $(6)$.

Amlodipin tarafindan tetiklenen dişeti hiperplazisine neden olan ortalama amlodipin dozu bazı çalışmalarda $5 \mathrm{mg} / g u ̈ n$ olarak bildirilmiştir (7). Bazı kaynaklar ise dişeti hiperplazisinin
Tablo 2. Amlodipin yan etkileri (2)

\begin{tabular}{ll}
\hline Kardiyovasküler sistem & $\begin{array}{l}\text { Flushing (kadınlarda daha } \\
\text { yaygın), çarpıntı, periferik ödem } \\
\text { (kadınlarda daha yaygın) }\end{array}$ \\
\hline Merkezi sinir sistemi & Baş dönmesi, uyuşukluk, halsizlik \\
\hline Dermatolojik & Kaşıntı, deri döküntüsü \\
\hline Gastrointestinal sistem & Karın ağrısı, bulantı \\
\hline Nöromüsküler ve iskelet sistemi & Kas krampları \\
\hline Solunum sistemi & Dispne, akciğer ödemi \\
\hline Nadir yan etkileri & $\begin{array}{l}\text { Akut interstisyel nefrit, } \\
\text { anoreksi, atriyal fibrilasyon, } \\
\text { bradikardi, kolestaz, konjonktivit, } \\
\text { depresyon, ishal, diplopi, } \\
\text { disfaji, epistaksis, eritem, dişeti } \\
\text { hiperplazi, jinekomasti, hepatit, } \\
\text { hiperglisemi, hipoestezi, serum } \\
\text { transaminazlarında artış, susuzluk } \\
\text { hissi, uykusuzluk, lökopeni, } \\
\text { makülopapüler döküntü, miyalji, } \\
\text { pankreatit, parestezi, periferik } \\
\text { iskemi, periferik nöropati, } \\
\text { fototoksisite, purpura, taşikardi, } \\
\text { trombositopeni, tremor, vaskülit, } \\
\text { kilo alımı }\end{array}$ \\
\hline
\end{tabular}

amlodipin dozundan bağımsız olduğunu bildirmiştir (8). OIgumuz dişeti hiperplazisi saptandığında amlodipini $2,5 \mathrm{mg} /$ gün dozunda 9 ay boyunca kullanmaktaydı. Genellikle, dişeti belirtileri ilaç uygulamasının ilk üç ayında görülür. Kötü oral hijyen, yaş, cinsiyet dişeti büyümesi için risk faktörüdür. Dişeti hiperplazisi erkeklerde kadınlara göre 3,3 kat daha sık görülür (7). Ayrıca genetik faktörlerin hiperplazi patogenezinde önemli rol oynayabileceği düşünülmektedir (9).

Hiperplazinin nedeni kesin olarak bilinmemekle birlikte, enflamatuar ve enflamatuar olmayan yolları içeren mekanizmalar öne sürülmüştür (Şekil 1) (10). Folik asit alımının az olması, keratinosit büyüme faktörünün artması, adrenal kortekste aldosteron sentezinin azalmasına bağlı olarak ACTH seviyesinin artması gibi inflamatuar olmayan mekanizmaların kollajenaz aktivitesini azaltarak dişeti hiperplazisine neden olduğu düşünülmektedir. Folik asit kalsiyum ile beraber hücre içine alınmaktadır. Amlodipin kalsiyumun hücre içine akımını azaltır, bu durum folik asitin de hücre içine alımında azalmaya neden olarak aktif kollajenaz üretimini sınırlar. Parçalanamayan kollajen diş etinin bağ dokusu matriksinde birikir (9). Alternatif olarak enflamasyon oral kavitede ve diş eti dokusunda ilacın toksik etkilerinin bir sonucu olarak gelişebilir (9). Toksik etki ve diş plağının etkisiyle TGF- $\beta 1$ gibi birçok sitokin seviyesinde artış olur. Sonuç olarak fibroblast proliferasyonu indüklenerek dişeti hiperplazisi gelişir (Şekil 1).

Gingival hipertrofi tedavi edilmezse, kanamaya, enfeksiyona, ülserasyona, kozmetik sorunlara ve çiğneme, konuşma bozuklukları gibi fonksiyonel sorunlara yol açabilir. Dişeti hiperplazisi tedavisinde sorumlu ilacın kesilmesi, oral kavite temizliği ve cerrahi seçenekler bulunmaktadır (1). 


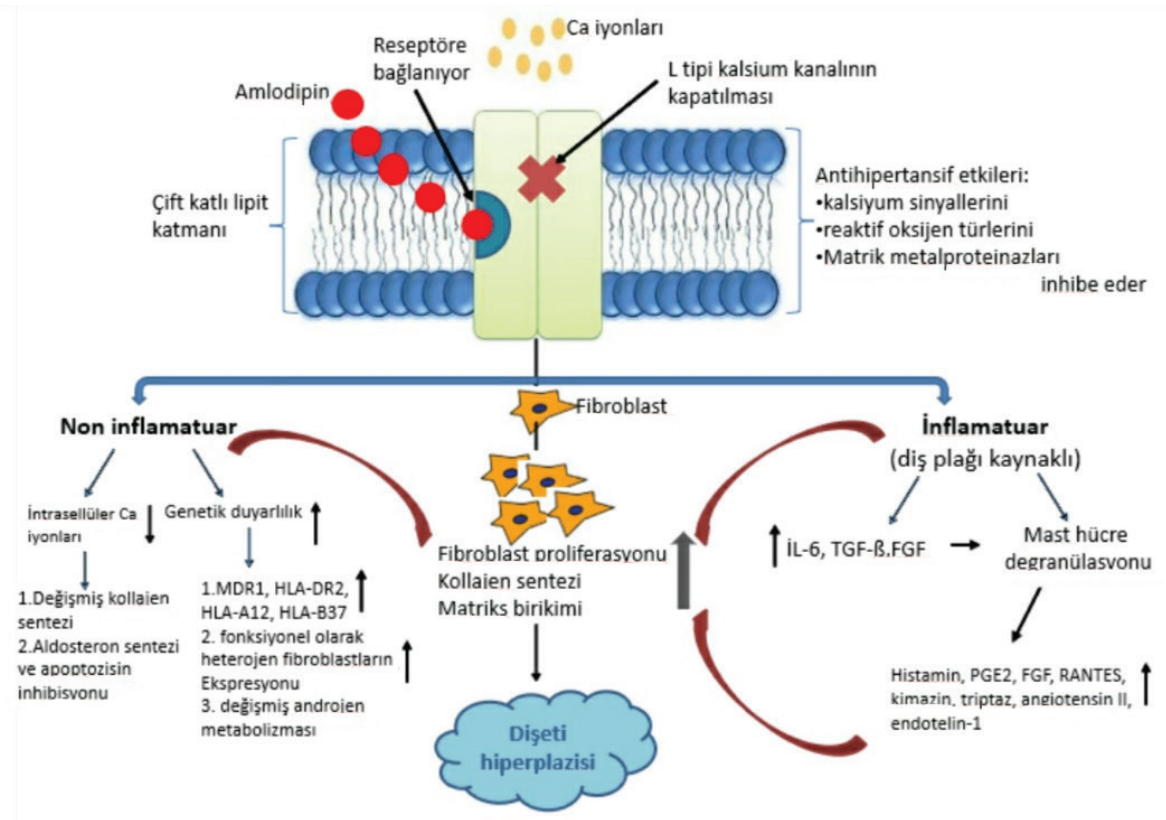

Şekil 1. Amlodipin tarafından tetiklenmiş dişeti hiperplazisinin patogenezi (1)

MDR1: multidrug resistance protein 1, HLA-DR2: human leukocyte antigen DR2 isotype, HLA-A12: human leukocyte antigen A12 isotype, HLA-B37: human leukocyte antigen B37 isotype, IL-6: interleukin 6, TGF- $\beta$ : transforming growth factor beta, FGF: fibroblast growth factor, PGE2: prostaglandin E2, RANTES: Regulated on Activation, Normal T Cell Expressed and Secreted

Bu olgu sebebiyle çocuklarda düşük dozda amlodipin kullanımında nadir de olsa dişeti hiperplazisinin gelişebileceğini, bu sebeple bu hastaların kontrollerinde ağız muayenesinin de gerekliliği akılda tutulmalıdır.

Bilgilendirilmiş Onam: Katılımcılardan bilgilendirilmiş onam alınmıştr.

Hakem Değerlendirmesi: Dış bağımsız.

Yazar Katkıları: Çalışma Konsepti/Tasarım- A.P.G.Ç.; Veri ToplamaL.A.; Yazı Taslağı- L.A.; İçeriğin Eleştirel İncelemesi- A.P.G.Ç.; Son Onay ve Sorumluluk- A.P.G.Ç., L.A.; Malzeme ve Teknik Destek- L.A.; Süpervizyon- A.P.G.Ç.

Çıkar Çatışması: Yazarlar çıkar çatışması beyan etmemişlerdir.

Finansal Destek: Yazarlar finansal destek beyan etmemişlerdir.

Informed Consent: Written consent was obtained from the participants.

Peer Review: Externally peer-reviewed.

Author Contributions: Conception/Design of Study- A.P.G.Ç.; Data Acquisition-L.A.; Drafting Manuscript- L.A.; Critical Revision of Manuscript- A.P.G.Ç.; Final Approval and Accountability- A.P.G.Ç., L.A.; Technical or Material Support- L.A.; Supervision- A.P.G.Ç.

Conflict of Interest: Authors declared no conflict of interest.

Financial Disclosure: Authors declared no financial support.

\section{KAYNAKLAR/REFERENCES}

1. Tungare S, Paranjpe AG. Drug Induced Gingival Overgrowth. In: StatPearls [Internet]. Treasure Island (FL): StatPearls Publishing; 2020. https://www.ncbi.nlm.nih.gov/books/NBK538518/

2. Amlodipine. Drug information. https://www.uptodate.com/contents/ amlodipine-drug-information.

3. Ellis JS, Seymour RA, Thomason JM, Monkman SC, Idle JR. Gingival sequestration of amlodipine induced gingival overgrowth. Lancet 1993;341:1102-3.

4. Jorgensen MG. Prevalence of amlodipine-related gingival hyperplasia. J Periodontol 1997;68(7):676-8.

5. Ellis JS, Seymour RA, Steele JG, Robertson P, Butler TJ, Thomason JM. Prevalence of gingival overgrowth induced by calcium channel blockers: a community-based study. J Periodontol 1999;70(1):63-7.

6. Ono M, Tanaka S, Takeuchi R, Matsumoto H, Okada H, Yamamoto $\mathrm{H}$, et al. Prevelance of amlodipine-induced gingival overgrowth. Int J Oral-Med Sci 2010;9(2):96-100.

7. Tripathi AK, Mukherjee S, Saimbi CS, Kumar V. Low dose amlodipine-induced gingival enlargement: A clinical case series. Contemp Clin Dent 2015;6(1):107-9.

8. Keels MA. Soft tissue lesions of the oral cavity in children. 2019 Jun: https://www.uptodate.com/contents/soft-tissue-lesions-ofthe-oral-cavity-in-children.

9. Lauritano D, Lucchese A, Stasio DD, Vella FD, Cura F, Palmieri A, et al. Molecular aspects of drug-induced gingival overgrowth: an in vitro study on amlodipine and gingival fibroblasts. Int J Mol Sci 2019;20(8):2047.

10. Gaur S, Agnihotri R. Is dental plaque the only etiological factor in amlodipine induced gingival overgrowth? A systematic review of evidence. J Clin Exp Dent 2018;10(6):610-9. 